\title{
Results of neuromodulation for the management of chronic pain
}

\section{Wyniki neuromodulacyinego leczenia bólu przewlekłego}

\author{
Paweł Sokal, Marek Harat, Dariusz Paczkowski, Marcin Rudaś, Marcin Birski, Aleksander Litwinowicz \\ Department of Neurosurgery, 10 th Military Clinical Hospital, Bydgoszzz, Poland
}

Neurologia i Neurochirurgia Polska 2011; 45, 5: 445-451

\begin{abstract}
Background and purpose: Neuromodulative treatment of chronic pain syndromes is a modern mode of treatment of neuropathic and ischaemic pain. Its effectiveness is well documented in the literature. The objective of this work is to present the results of treatment of chronic pain syndromes on the basis of eight-year experience in our department.

Material and methods: Since 2002, we have conducted 9 operations of motor cortex stimulation (MCS), 2 of deep brain stimulation (DBS), 45 of spinal cord stimulation (SCS) and 5 of sacral root stimulation (SRS) in the treatment of chronic pain.

Results: We obtained good long-term results of neuromodulation in the form of clinical improvement $(>50 \%)$ in 4 of 9 patients with MCS (44\%), in 13 diagnosed with failed back surgery syndrome (FBSS), 8 with other neuropathic pain, and 11 with angina pectoris from a group of 45 treated with SCS. Sacral root stimulation has been successful in 3 of 5 patients with perianal pain. The best treatment results in SCS, although not statistically significant, were observed in patients treated due to FBSS (13 out of 15) and angina pectoris (11 out of 15 ) $(p=0.12)$. In patients with neuropathic pain, peripheral and central, improvement was obtained in 8 out of 15 patients.

Conclusions: A good indication for spinal cord stimulation is FBSS and angina pectoris. Motor cortex stimulation is helpful in the treatment of chronic central neuropathic pain. Further observations and a larger group of patients are necessary for a reliable assessment of the effectiveness of neuromodulative treatment of chronic pain in our clinic.
\end{abstract}

\section{Streszczenie}

Wstęp i cel pracy: Neuromodulacyjne leczenie bólu przewlekłego to nowoczesna forma leczenia bólu neuropatycznego i niedokrwiennego. Jego efektywność została dobrze udokumentowana w piśmiennictwie. Celem pracy jest przedstawienie wyników leczenia przewlekłych zespołów bólowych na podstawie ośmioletniego doświadczenia kliniki autorów.

Materiał i metody: Od 2002 r. w leczeniu bólu przewlekłego przeprowadzono 9 zabiegów stymulacji kory mózgu (MCS), 2 głębokiej stymulacji mózgu (DBS), 45 stymulacji rdzenia kręgowego (SCS) i 5 stymulacji korzeni krzyżowych (SRS). Wyniki: Otrzymano dobre odległe wyniki neuromodulacji w postaci poprawy klinicznej (co najmniej o 50\%) u 4 spośród 9 pacjentów z MCS (44\%), u 13 z rozpoznaniem dyskopatii lędźwiowej (FBSS) oraz u 8 z innym bólem neuropatycznym, a także u 11 z dusznicą bolesną z grupy 45 poddanych SCS. Stymulacja korzeni krzyżowych była skuteczna u 3 spośród 5 pacjentek z bólem okolicy okołoodbytniczej. Najlepsze wyniki leczenia, choć nieznamienne statystycznie, zaobserwowano w SCS u pacjentów leczonych z powodu zespołu bólowego kręgosłupa o typie FBSS (13 spośród 15 pacjentów) oraz dławicy piersiowej (11 spośród 15$)(p=0,12)$. W grupie pacjentów $z$ bólem neuropatycznym obwodowym i ośrodkowym poprawę uzyskano u 8 spośród 15 osób.

Wnioski: Dobrymi wskazaniami do stymulacji rdzenia kręgowego są przewlekły zespół bólowy o typie FBSS i dusznica bolesna. Stymulację kory mózgu można z powodzeniem stosować w leczeniu ośrodkowego bólu neuropatycznego. Do przeprowadzenia wiarygodnej oceny skuteczności leczenia

Correspondence address: dr Paweł Sokal, Klinika Neurochirurgii, 10. Wojskowy Szpital Kliniczny, ul. Powstańców Warszawy 5, 85-681 Bydgoszcz, Poland, phone +4852378 7093, fax +48523787094, e-mail: psokal@wp.pl

Received: 13.01.2011; accepted: 6.04 .2011 
Key words: neuromodulation, chronic pain, spinal cord stimulation, motor cortex stimulation.

\section{Introduction}

Since the introduction of gate theory by Melzack and Wall in 1965 and performance of the first spinal cord stimulation procedure by Shealy et al. in 1967, hundreds of investigators and clinicians have proceeded with neuromodulative procedures and a plethora of publications have revealed positive effects of this kind of treatment in chronic pain $[1,2]$. Neuromodulative procedures are superior to neuroablative approaches in two main aspects: they are reversible and safe. The following neuromodulative procedures are the most common in chronic pain: peripheral nerve stimulation (PNS), spinal cord stimulation (SCS), deep brain stimulation (DBS), motor cortex stimulation (MCS), and the intrathecal infusion system (IIS). Sacral root stimulation (SRS), targeted neurostimulation (TNS), drug-enhanced spinal cord stimulation and procedures combining two methods, e.g. SCS and targeted subcutaneous stimulation [3-5], play an important role in specific pain syndromes.

The mechanism of action of all neuromodulative approaches in chronic pain has not yet been fully elucidated. There are several plausible analgesic effects of spinal cord stimulation. The first theory explains inhibition of transmission of nociceptive impulses by activation of large dorsal fibres in dorsal horns; electric stimulation can cause segmental inhibition or activation of the anterior pretectal nucleus. Linderloth postulates a mechanism activating GABA-b receptors, which suppresses the excitatory, nociceptive effect in dorsal horn cells; other neurotransmitters such as serotonin, glycine and adenosine are to play a pivotal role in inhibition of neuropathic pain. In ischaemic pain, besides chemical action, autonomic activity of SCS, especially suppression of sympathetic excitation, is crucial [6-8]. In MCS and DBS, suppression of transmission of nociceptive stimuli in thalamic nuclei might be the factor responsible for pain diminution [9-12].

The main indication for neuromodulation is neuropathic and ischaemic pain [13-20]. Several particular methods are characteristic and the most suitable for appropriate types of pain. Motor cortex stimulation is neuromodulacyjnego bólu przewlekłego w klinice autorów niezbędne są dalsze obserwacje i większa grupa pacjentów poddanych różnym procedurom.

Słowa kluczowe: neuromodulacja, ból przewlekły, stymulacja rdzenia kręgowego, stymulacja kory mózgu.

a method applicable in neuropathic pain of thalamic syndrome, post-stroke pain, in pain after spinal cord injury or brachial plexus injury, in atypical facial pain and atypical trigeminal neuralgia [11,21-25]. Similar indications, and additionally cluster headache, exist for DBS [12,26-28]. Spinal cord stimulation is in widespread use in failed back surgery syndrome (FBSS), chronic radicular pain, complex regional pain syndrome (CRPS), phantom limb pain, postherpetic neuralgia, peripheral vascular disease and angina pectoris [3,13,14,16-19,29-32] . Patients with occipital neuralgia and trigeminal neuralgia are qualified for PNS; other targets of nerve stimulation are median, radial, ulnar and tibial nerves; pelvic pain is an indication for SRS [5,33].

We always have to remember about proper selection of patients for neuromodulative procedures. The outcome of operative neuromodulation is conditioned by factors such as aetiology, timing of implantation, the sort of electrodes and type of pulse generator, programming and tolerance on pain development $[18,32,34,35]$. For instance, in SCS, the most satisfactory results can be achieved in neuropathic pain of FBSS and CRPS, also in refractory angina or peripheral vascular disease. Worse outcomes are in phantom pain, postherpetic neuralgia, pain due to spinal cord injury and perirectal pain or axial pain. The success rate is higher in cases with a shorter time interval between the beginning of chronic pain and the time of implantation. Better pain reduction of axial pain is achieved when dual electrodes are applied in SCS than single leads [34]. Over the years, techniques of operative neuromodulation have undergone significant changes and modernization. New strategies are less invasive, more popular and less costly. The most popular is SCS, which is available in the majority of departments of neurosurgery in Poland. In our department we started to conduct neuromodulative strategies for chronic pain in 2002, although we had performed neuroablative procedures previously [36].

\section{Material and methods}

Since 2002, 9 procedures of MCS, 2 of DBS, 45 of SCS and 5 of sacral stimulation have been performed in 
the Department of Neurosurgery of the Military Clinical Hospital.

The group of patients qualified for MCS consisted of patients with chronic neuropathic pain of thalamic syndrome caused by stroke, intracerebral haemorrhage, multiple sclerosis, pain associated with syringomyelia, chronic pain due to brachial plexus injury and atypical facial pain. All MCS implantations were done under general anaesthesia without muscular relaxation, with craniotomies contralateral to the pain side; electrodes were placed on dura and in four cases directly on the motor cortex guided by neuronavigation and neurophysiological neuromonitoring (Fig. 1). Monitoring of motor evoked potentials (MEP), and in several cases somatosensory evoked potentials (SSEP), enabled us to localize the motor and sensory cortex and central sulcus. Pulse generators connected by wires to electrodes were implanted in subcutaneous pockets in the subclavicular area.

In DBS, we used a stereotactic frame and BrainLab Iplan software which enables planning of stereotactic implantation of deep brain electrodes. In both our cases we localized tips of electrodes in the posterior part of the internal capsule. The target proposed by Richardson seemed to be the most suitable for us [37]. Deep brain stimulation implantations were performed in local anaesthesia under fluoroscopic control [38].

Spinal cord stimulation is a pain procedure conducted in pain clinics and neurosurgical departments. In our department, we generally implant paddle type electrodes surgically, placing them on the dural sac after central flavectomy or partial laminectomy anchoring leads to fascia, connecting to an internal pulse generator placed in a subcostal, subcutaneous pocket on the right or left side. These procedures are performed under general anaesthesia. Nowadays, we generally do a one-stage operation of spinal cord stimulator implantation. We believe that a second operation after a trial period with external stimulation can be avoided in the majority of cases. An eventual second intervention is necessary when a paddle type electrode is placed in the wrong place, i.e. slightly too laterally, or at the wrong level. It is important to point out here that a percutaneous procedure under local anaesthesia is superior due to the possibility of intraoperative stimulation, but it is less convenient for the patient and there is a higher risk of lead electrode migration. In pain located in lower legs and in the lumbar area, we usually implant electrodes at the Th10 level, in angina pectoris at the Th2 level, in intercostal neuralgia at the appropriate Th level above, in pain comprising upper limbs at C2-3 levels. In four cases, percutaneous electrodes

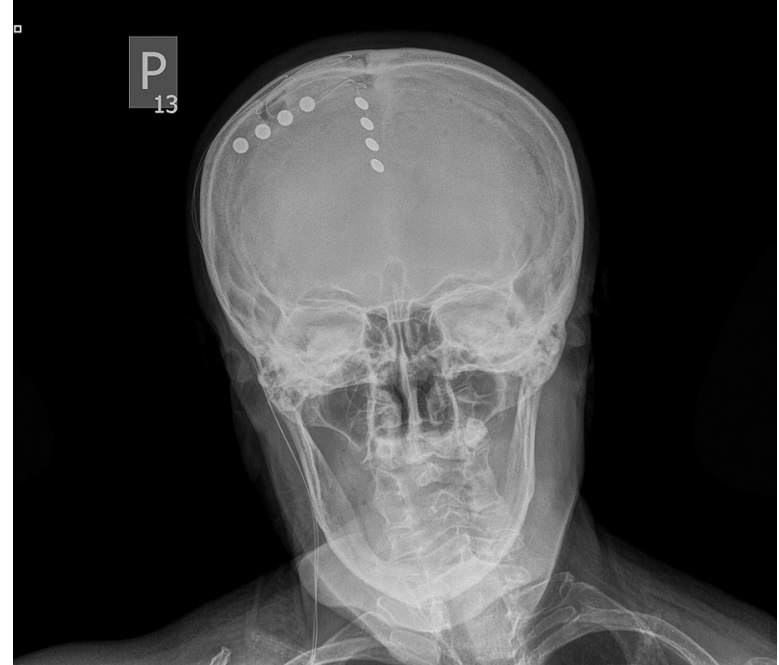

Fig. 1. Motor cortex stimulation in thalamic pain located in lower and upper extremities. Two four-polar electrodes placed on precentral gyrus and in interhemispheric fissure

were implanted through the sacral hiatus in order to stimulate sacral roots in perianal pain (Fig. 2). All patients were hospitalized several days after surgery and parameters of stimulation were adjusted individually.

Among 15 patients with angina pectoris, 2 were women, 13 men, 10 had experienced myocardial infarction before. All patients were qualified for SCS due to ineffective pharmacotherapy and when all the possibilities of revascularisation procedures had been completed. All had undergone cardiological, cardiosurgical and neurosurgical consultations confirming the diagnosis and proper qualification.

Effects of treatment were assessed on a visual analogue scale. Intensity of pain was assessed after surgery, one month after surgery and later on every 3 or 6 months. Not all patients were able to attend scheduled visits. In many cases, information about effects of neuromodulation was obtained by telephone. Presented results describe the state of efficacy in various patients with different periods of observation (from 3 months to 8 years) in Autumn 2010.

\section{Results}

\section{Effects of motor cortex stimulation}

Nine patients were operated on; in two patients (one with atypical facial pain, the other with pain related to brachial plexus injury) we had no improvement, in three 



Fig. 2. Afferent sacral root stimulation in perianal pain

cases (two with thalamic syndrome, the third with hemibody pain related to syringomyelia) we obtained less than $50 \%$ improvement, in four patients (two cases with thalamic syndrome and two with atypical facial pain) we observed over $50 \%$ long-term improvement (including two cases with $90 \%$ improvement). In the last subgroup, in two cases we placed electrodes directly on the cortex subdurally. These patients were able to significantly reduce doses of analgesics, mostly tramadol. Patients with neuropathic pain also used gabapentin and carbamazepine additionally.

\section{Effects of spinal cord stimulation in neuropathic pain}

Among 30 patients with SCS due to neuropathic pain (excluding patients with angina pectoris), we had no improvement in five cases: two cases with pain related to spinal cord injury, one patient with pain caused by myelitis, one patient with phantom pain and another one with pain due to brachial plexus injury. In other four cases (one with intercostal neuralgia, two with anal pain and one with neuropathic pain due to conus medullaris injury) preliminary good effects deteriorated to a worse response, which was estimated as a lack of any improvement. In 8 patients $(26 \%)$ with follow-up longer than 12 months we observed worsening of the initial satisfactory effect which later was assessed as a moderate effect with improvement of less than 50\% (patients with FBSS, syringomyelia and CRPS type 2). A good long-term result of neuromodulation in the form of clinical improvement (at least 50\%) was obtained in 13 patients diag- nosed with FBSS and 8 patients with other neuropathic pain. The best treatment results in SCS, although not statistically significant, were observed in patients treated due to FBSS (13 out of 15 patients, 86\%) ( $p=0.12$ ). In other patients with neuropathic pain, peripheral or central, significant improvement was noted in 8 patients out of $15(53 \%)$. Patients who had an excellent result usually did not use analgesics; frequently they reduced doses and even withdrew nonsteroidal drugs and tramadol. Others, with worse effects, had to sustain analgesics, antidepressants and anxiolytic drugs.

\section{Effects of spinal cord stimulation in angina pectoris}

Fifteen patients with angina pectoris treated with SCS remained satisfied in long-term follow-up. All patients after implantation achieved significant alleviation of pain, in 11 patients (73\%) alleviation was complete (VAS $=0$ ). Reduction of incidence of anginal attacks and improvement of physical capacity was observed. Standard exercise tests and scintigraphy tests revealed improved myocardial perfusion with increased total ejection fraction. In all patients, doses of long-acting nitrates were decreased. Neurostimulator caused reduction of administered nitrates with complete withdrawal of them in $40 \%$ (6 patients) $[39,40]$. They used short-acting nitrates very seldom. Two patients died, one due to pulmonary embolism and the second by suicide. Statistical analysis documented reduction of costs of refractory angina pectoris treatment after stimulator implantation. In five years perspective, costs of treatment were de- 
creased by $41 \%$. The cost of the neurostimulator and its implantation should be returned in 10 years [41].

\section{Effects of sacral root stimulation}

Five patients with chronic perianal and rectal pain were treated with SRS. In one patient two methods were applied: first, conus medullaris stimulation; secondly, SRS. Operations were performed under general anaesthesia and electrodes were implanted under fluoroscopic control percutaneously through the sacral hiatus. Satisfactory results have been achieved - improvement around or over $50 \%$ in three cases [42].

\section{Complications}

In $9 \mathrm{MCS}$ procedures, we had 3 events of epileptic seizures during intraoperative stimulation and one event postoperatively; after reduction of stimulation parameters it did not occur again. No other complications were observed in MCS. In DBS we noted one event of migration of an electrode 2 months after implantation and lack of stimulation effects. In the stereotactic procedure, the main complications are intracerebral haemorrhage (below 5\%) [12] and increased risk of infection (up to $12 \%)[12,43]$ or annoying paraesthesias [28]. In SCS procedures we had two cases of epidural haematoma in the spinal canal which had to be evacuated. One was symptomatic with paraparesis. It was the patient with angina pectoris who had been receiving antiplatelet drugs preoperatively. We noted one case of breakage of a lead due to increased tension in the place where it was connected to the electrode lead. Three times we had to change the position of the electrode due to insufficient coverage of the area of pain. In two cases it was necessary to remove the stimulation system due to infection after SRS procedures.

\section{Discussion}

Neuromodulation therapy modulates activity of the nervous system and is a highly specific and reversible mode of treatment of pain of various origin. Neurostimulation devices involve the application of electrodes into or on the brain, over the spinal cord or to peripheral nerves. The most common worldwide and in Poland is SCS to treat chronic neuropathic pain. The best indications for SCS are neuropathic pain and ischaemic pain in coronary artery disease and peripheral vascular disease $[20,32,44]$. In our department, patients treated with SCS constitute the majority of patients managed with neuromodulation due to chronic neuropathic pain or angina.

According to our experience and the experience of others, a key to success is the right choice of patient and the right choice of indication $[32,34,44]$. Patients with long-standing pain have lower chance of a successful effect than those who do not wait for implantation so long $[32,34]$. In our material, all patients who had a poor result had had a long history of pain before implantation (mean: 9 years). Patients with significant improvement had mean pain duration of 6.8 years. We have not found a statistically significant difference in the Cochran-Cox test between these groups, probably due to the small number of subjects in both groups. Another very important factor influencing the final effect is the aetiology of pain. Worse results have been observed in neuropathic pain associated with central nervous system injury, i.e. anaesthesia dolorosa in MCS and DBS, pain due to spinal cord haematoma or spinal cord injury and brachial root avulsion, postherpetic intercostal neuralgia or phantom pain. We have not found a statistically significant relationship between FBSS, angina pectoris and other types of pain and the result $(p=0.12)$. The best effects can be achieved in patients with FBSS and angina pectoris. This statement remains in accordance with the observations of others having much greater material $[32,34,44]$. Distribution of pain is also another crucial factor. It is much easier to alleviate pain localized in the extremities, and it is rarely possible to remove axial pain in the midlumbar area or in the scrotal and anal region using SCS $[14,19,32]$. Patients with perianal pain are qualified for SRS.

In our department, patients are scheduled to be followed up every 3 months. The majority of them attend the control visit due to aggravation of symptoms or lack of perception of paraesthesias produced by the stimulator. According to our experience, patients usually have a problem with proper estimation of intensity of pain and grade of improvement. They have difficulties with objective assessment of effects of stimulation after modification of parameters. It is much easier for them to determine the area of paraesthesias induced by the stimulator. In some cases it is possible to cover the area of pain with stimulation; thus we can reduce the level of pain but not enough to satisfy the patients. In our material, 21/30 patients with SCS (excluding angina) had a satisfactory effect (over 50\%) or almost satisfactory effect (40-50\%). These data are changing all the time because some patients are never certain in their subjective assessment. On 
the other hand, among them there are people who are convinced of the beneficial influence of SCS. In general, effects of SCS in our patients are positive and only one patient after 3 years of successful analgesic therapy asked us to remove the internal power generator (IPG) due to unpleasant paraesthesias affecting the whole body. Effectiveness of SCS is estimated at around 65\% [30]. The percentage of patients with FBSS who have clinical improvement over $50 \%$ is about $50-62 \%, 40 \%$ of patients return to work activities, $70 \%$ can feel satisfaction, and $53 \%$ of patients withdraw analgesic drugs $[18,19]$. Better results can be achieved in CRPS type 2 (causalgia) and type 1 (reflex sympathetic dystrophy), 79-82\%, or in peripheral ischaemic pain, over $70 \%$ [17] and especially in angina pectoris. Around $80 \%$ of patients experience significant long-term improvement of comfort of life and increase in social activity with a reduction of the number of anginal attacks [16].

Complications associated with SCS can be divided into surgical complications, which are infection, CSF leakage, epidural haemorrhage, and mechanical spinal cord injury (5-9\%) [44]; and the second group of complications, associated with breakage of the lead, migration or transposition of the electrode and IPG. The latter are more frequent and account for about 10-30\% of patients $[30,44]$. The diminution of effects of stimulation is caused by development of tolerance of pain and underlying disease. The median percentage of hardware failures was calculated to be $6.5 \%$, ranging from 0 to $40 \%[19,44]$.

Among nine patients who were treated with MCS, complete lack of improvement was noted in two patients: one with neuropathic pain caused by avulsion of the brachial plexus, the second with long-lasting anaesthesia dolorosa in the trigeminal area. According to the data of others, satisfactory results can be achieved in central pain and neuropathic trigeminal pain [23]. In our material we have one female patient with atypical facial pain with significant improvement of at least $50 \%$ who had reimplantation of the IPG due to depletion of the battery. An excellent result can be observed in one patient with thalamic syndrome who has one electrode implanted subdurally along the motor cortex, following patients with two electrodes: one placed subdurally in the interhemispheric fissure and the second implanted on the dura estimate the effect as satisfactory around $40 \%$ to $50 \%$ on the lower and upper extremity (Fig. 1). In MCS, stimulation is set at a lower frequency than in SCS $(40-50 \mathrm{~Hz})$ and a shorter pulse wave (100-140 ms); amplitude is adjusted to the level which prevents epileptic seizure occurrence. Paraesthesias are rarely perceived in MCS. Satisfactory long-term improvement is observed in three cases in patients with central neuropathic pain, but our group consists only of 9 subjects and it is difficult to draw plausible conclusions.

\section{Conclusions}

1. A good indication for SCS is FBSS and angina pectoris.

2. The majority of patients with chronic pain experience relief of pain after stimulation.

3. Motor cortex stimulation is helpful in central neuropathic pain.

4. Patients should remain under control of the neurosurgical centre for follow-up and periodic changes in the parameters of stimulation.

5. Further observations and a larger group of patients undergoing different procedures are necessary for a reliable assessment of the effectiveness of neuromodulative treatment of chronic pain in our clinic.

\section{Disclosure}

The authors report no conflict of interest.

\section{References}

1. Melzack R., Wall P.D. Pain mechanisms: a new theory. Science 1965; 150: 971-979.

2. Shealy N., Taslitz N., Mortimer J.T., et al. Electrical inhibition of pain: experimental evaluation. Anesth Analg 1967; 46: 299-305.

3. Alo K.M., Holsheimer J. New trends in neuromodulation for the management of neuropathic pain. Neurosurgery 2002; 50: 690-704.

4. Goroszeniuk T., Kothari S. Subcutaneous targeted stimulation. In: Krames E., Peckham P.H., Rezai A.R. [eds.]. Neuromodulation. Elsevier, London 2009, pp. 417-427.

5. Weiner R.L., Reed K.L. Peripherial neurostimulation for control of intractable occipital neuralgia. Neuromodulation 1999; 2: 217-221.

6. Cui J.G., Linderoth B., Meyerson BA. Effects of spinal cord stimulation on touch-evoked allodynia involve GABA-ergic mechanisms. An experimental study on mononeuropathic rat. Pain 1996; 66: 287-295.

7. Larson S.J., Sances A., Riegel D.H., et al. Neurophysiological effects of dorsal column stimulation in man and monkey. J Neurosurg 1974; 41: 217-223.

8. Linderoth B., Meyerson B.A. Spinal cord stimulation: mechanism of action. In: Burchiel K.J. [ed.]. Surgical management of pain. Thieme, New York 2002, pp. 505-526.

9. Droutot X., Nguyen J.P., Peschanski M., et al. The antalgic efficacy of chronic motor cortex stimulation is related to sensory changes in the painful zone. Brain 2002; 125: 1660-1664. 
10. Garcia-Larrea L., Peyron R., Mertens P., et al. Electrical stimulation of motor cortex for pain control: a combined PET-scan and electrophysiological study. Pain 1999; 83: 259-273.

11. Tsubokawa T., Katayama Y., Yamamoto T., et al. Chronic motor cortex stimulation in patients with thalamic pain. J Neurosurg 1993; 78: 393-401.

12. Tronnier V.M. Deep brain stimulation. In: Simpson B.A. [ed.]. Electrical stimulation and the relief of pain. Elsevier, Amsterdam 2003, pp. 211-236.

13. Barolat G., Sharan A., Ong J. Spinal cord stimulation for back pain. In: Simpson B.A. [ed.]. Electrical stimulation and the relief of pain. Elsevier, Amsterdam 2003, pp. 79-85.

14. Bennett D.S., Cameron T.L. Spinal cord stimulation for complex regional pain syndromes. In: Simpson B.A. [ed.]. Electrical stimulation and the relief of pain. Elsevier, Amsterdam 2003, pp. 111129.

15. DeJongste M.J. Spinal cord stimulation for ischaemic heart disease. Neurol Res 2000; 22: 293-298.

16. Eliasson T., Dejongste M.J.L., Manheimer C. Neuromodulation for refractory angina pectoris. In: Simpson B.A. [ed.]. Electrical stimulation and the relief of pain. Elsevier, Amsterdam 2003, pp. 143-159.

17. Kumar K., Toth C., Nath R.K., et al. Improvement of limb circulation in peripheral vascular disease using epidural spinal cord stimulation: a prospective study. J Neurosurg 1997; 86: 662-669.

18. Taylor R.S., Van-Buyten J.P., Buchser E. Spinal cord stimulation for chronic back and leg pain and failed back surgery syndrome: a systemic review and analysis of prognostic factors. Spine 2005; 30: $152-160$

19. Turner J.A., Loesler J.D., Bell K.G., et al. Spinal cord stimulation for patients with failed back surgery syndrome or complex regional pain syndrome: a systemic review of effectiveness and complications. Pain 2004; 108: 137-147.

20. Ząbek M., Sławek J., Harat M., et al. Stymulacja mózgu i rdzenia kręgowego w leczeniu zaburzeń ruchowych oraz zespołów bólowych - podstawy teoretyczne i zalecenia praktyczne. Neurol Neurochir Pol 2006; 40: 1-9.

21. Brown J.A. Motor cortex stimulation. Semin Neurosurg 2004; 15: 177-182.

22. Katayama Y., Fukaya C., Yamamoto T. Poststroke pain control by chronic motor cortex stimulation: neurological characteristics predicting a favorable response. J Neurosurg 1998; 89: 585-591.

23. Nguyen J.P., Leaucheur J.P., Kreavel Y. Motor complex stimulation. In: Simpson B.A. [ed.]. Electrical stimulation and the relief of pain. Elsevier, Amsterdam 2003, pp. 197-209.

24. Sławek J., Ręcławowicz D., Zieliński P., et al. Stymulacja kory ruchowej w zespole bólu ośrodkowego. Neurol Neurochir Pol 2005; 39: $237-240$

25. Sokal P., Harat M., Gryz J., et al. Stymulacja kory mózgu w leczeniu bólu ośrodkowego - opis przypadku. Neurol Neurochir Pol 2006; 40: 253-257.

26. Bittar R.G., Kar-Purkayastha I., Owen S.L., et al. Deep brain stimulation for pain relief: a meta-analysis. $J$ Clin Neurosci 2005; 12: 515-519

27. Franzini A., Ferroli P., Leone M., et al. Hypothalamic deep brain stimulation for the treatment of chronic cluster headaches: a series report. In: Hilten B., Nuttin B. [eds.]. Proceedings of the
Medtronic Forum for Neuroscience and Technology 2005. Springer Medizin Verlag Heidelberg, Berlin, Heidelberg, New York 2007, pp. 48-50

28. Ray C.D., Burton C.V. Deep brain stimulation for severe chronic pain. Acta Neurochir Suppl (Wien) 1980; 30: 289-293.

29. Geert H.S. Spinal cord stimulation in peripherial vascular disease. In: Simpson B.A. [ed.]. Electrical stimulation and the relief of pain. Elsevier, Amsterdam 2003, pp. 132-142.

30. Kuchta J., Koulousakis A., Sturm V. Neurosurgical pain therapy with epidural spinal cord stimulation. Acta Neurochir Suppl 2007; 97: 65-70.

31. Oakley J.C. Spinal cord stimulation for neuropathic pain. In: Simpson B.A. [ed.]. Electrical stimulation and the relief of pain. Elsevier, Amsterdam 2003, pp. 87-109.

32. Van Buyten J.P., Van Zundert J., Vueghs P., et al. Efficacy of SCS: 10 years of experience in a pain center in Belgium. Eur J Pain 2001; 5: 299-307.

33. Hassenbusch S.J. Peripheral nerve stimulation. In: Follet K.A. Neurosurgical pain management. Elsevier, Amsterdam 2004, pp. 144-149.

34. Kumar K., Wilson J.R. Factors affecting spinal cord stimulation outcome in chronic benign pain with suggestions to improve success rate. Acta Neurochir Suppl 2007; 97: 91-99.

35. Simpson B. Selection of patients and assessment of outcome. In: Simpson B.A. [ed.]. Electrical stimulation and the relief of pain. Elsevier, Amsterdam 2003, pp. 237-249.

36. Harat M., Sokal P. Chirurgiczne leczenie zespołów bólowych w materiale Kliniki Neurochirurgii Wojskowego Szpitala Klinicznego w Bydgoszczy. Neurol Neurochir Pol 2004; 38: 90-91.

37. Richardson D.E. Internal capsule stimulation for pain control. Abstracts of the Proceedings of the XVIIth Congress of ESSFN. Acta Neurochir 2006; 148: 26.

38. Sokal P., Harat M., Rudaś M. Stymulacja torebki wewnętrznej metoda leczenia znieczulenia bolesnego twarzy. Ból 2007; 8: 48-54.

39. Sokal P., Harat M., Rusicka-Piekarz T. Stymulacja rdzenia kręgowego w krańcowej dusznicy bolesnej. Neurol Neurochir Pol 2005; 39: 417-419.

40. Sokal P., Harat M., Rusicka-Piekarz T., et al. Spinal cord stimulation in refractory angina pectoris - analysis of efficacy and costbenefits. Acta Neurochir 2008; 150: 972.

41. Cuprych A., Harat M., Rusicka-Piekarz T. Ocena ekonomiczna efektywności leczenia stymulatorem rdzenia kręgowego lekoopornej dusznicy bolesnej. Valetudin 2006; 11: 29-32.

42. Sokal P., Harat M. Stymulacja korzeni krzyżowych i stożka rdzenia w bólu krocza. Ból 2010; 11: 23-27.

43. Bhatia S., Zhang K., Oh M., et al. Infections and hardware salvage after deep brain stimulation surgery: a single-center study and review of the literature. Stereotact Funct Neurosurg 2010; 88: 147-155.

44. Turner J.A., Loeser J.D., Bell K.G. Spinal cord stimulation for chronic pain low back pain: a systemic literature synthesis. Neurosurgery 1995; 37: 1088-1095. 